\title{
EkoMiasto\#Społeczeństwo
}

Zrównoważony, inteligentny i partycypacyjny rozwój miasta

pod redakcją

Aleksandry Nowakowskiej, Zbigniewa Przygodzkiego, Agnieszki Rzeńcy 
http://dx.doi.org/10.18778/7969-221-7.04

Ewa M. Boryczka*

Jakub Zasina**

\section{DZIEDZICTWO KULTUROWE I TOŻSAMOŚĆ MIASTA}

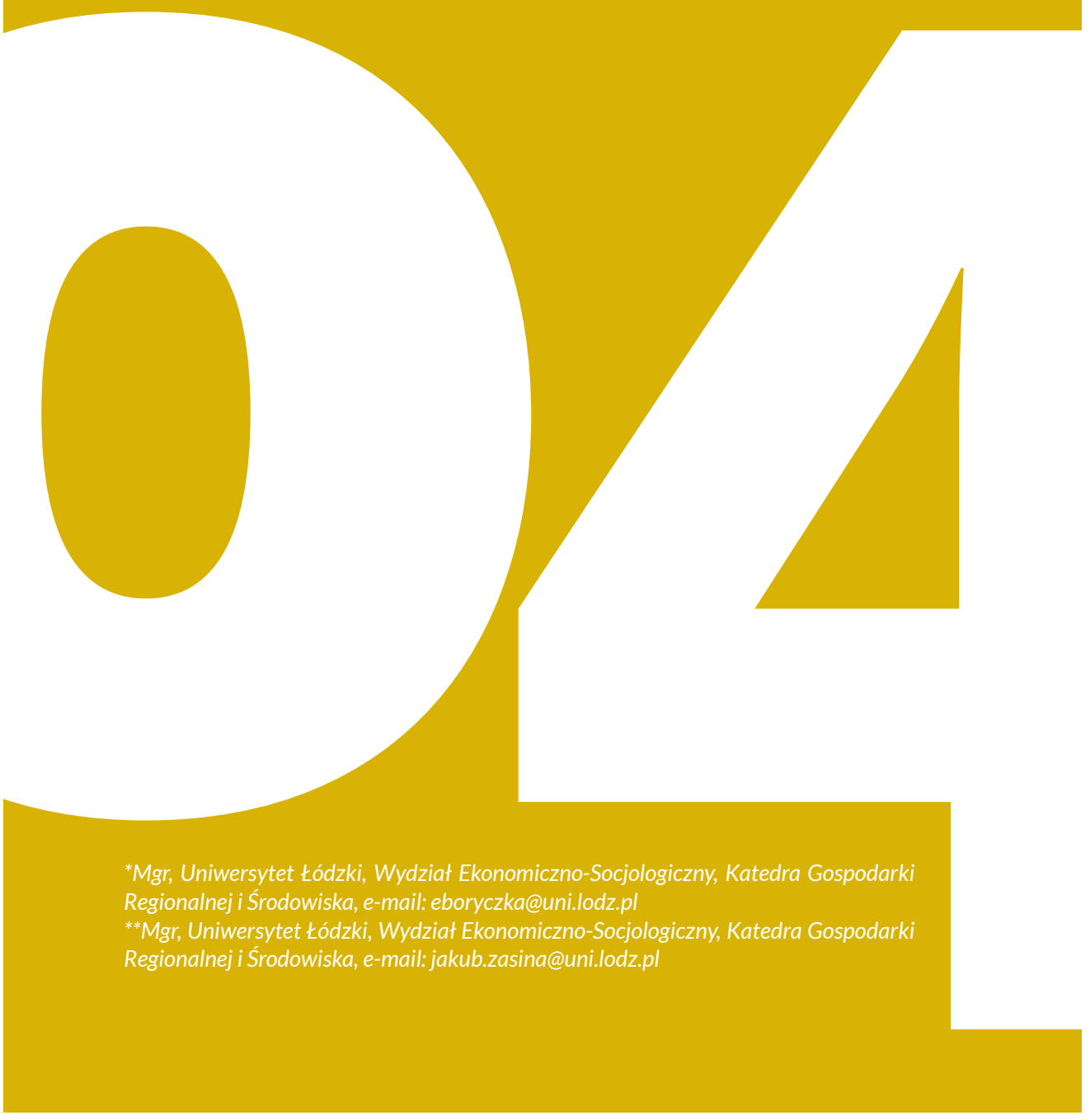




\subsection{Dziedzictwo kulturowe w rozwoju miasta}

\subsubsection{Istota dziedzictwa kulturowego}

Termin „zabytek” zdążył się rozpowszechnić w codziennym języku: przewodnicy posługują się nim, opowiadając o zabytkowych budowlach; kolekcjonerzy przyozdabiają mieszkania zabytkowymi meblami; miłośnicy motoryzacji uczestniczą w zjazdach zabytkowych pojazdów. Zabytek jest intuicyjnie postrzegany jako coś wiekowego. W ostatnich latach można było usłyszeć budzące kontrowersje dyskusje na temat tego, czy dany budynek jest już „wystarczająco stary”, aby stać się zabytkiem. Nie istnieje jednak granica, której przekroczenie gwarantowałoby uzyskanie statusu zabytku. Kto zatem i na jakiej podstawie decyduje o tym, czy dany obiekt określimy takim mianem? Zazwyczaj decyzję tę podejmują konserwatorzy na podstawie analizy wartości kulturowych danego obiektu, m.in. wartości historycznej, estetycznej, naukowej i autentyczności. Wysiłki podejmowane przez konserwatorów prowadzą do stworzenia katalogu zabytków o określonej liczbie pozycji. Oznacza to jednak, że choć dany obiekt może cechować się pewnymi wartościami kulturowymi, niekoniecznie musi on posiadać formalny status obiektu zabytkowego.

\section{Aż budynek stanie się zabytkiem}

Analiza przeprowadzona na podstawie danych z rejestru zabytków miasta Katowice wykazała, że przeciętnie upływa tam 91 lat od daty wzniesienia budynku do momentu, kiedy trafia on do rejestru zabytków. Mija bowiem pewien okres, zanim środowisko konserwatorskie uzna dany obiekt za warty ochrony. Katowice odnotowały etap najbardziej dynamicznego rozwoju na przełomie XIX i XX w., zatem można się spodziewać, że to właśnie z tego okresu pochodzić będzie znaczna część tamtejszej zabudowy. Jak wynika z poniższego wykresu, jeszcze w latach 70. stosunkowo niewiele katowickich budynków było wpisywanych do rejestru zabytków. W miarę, jak przekonanie o wartości zabudowy XIX i XX-wiecznej rosło, wytężenia nabierały wysiłki konserwatorów, aby obejmować tę zabudowę prawną ochroną.

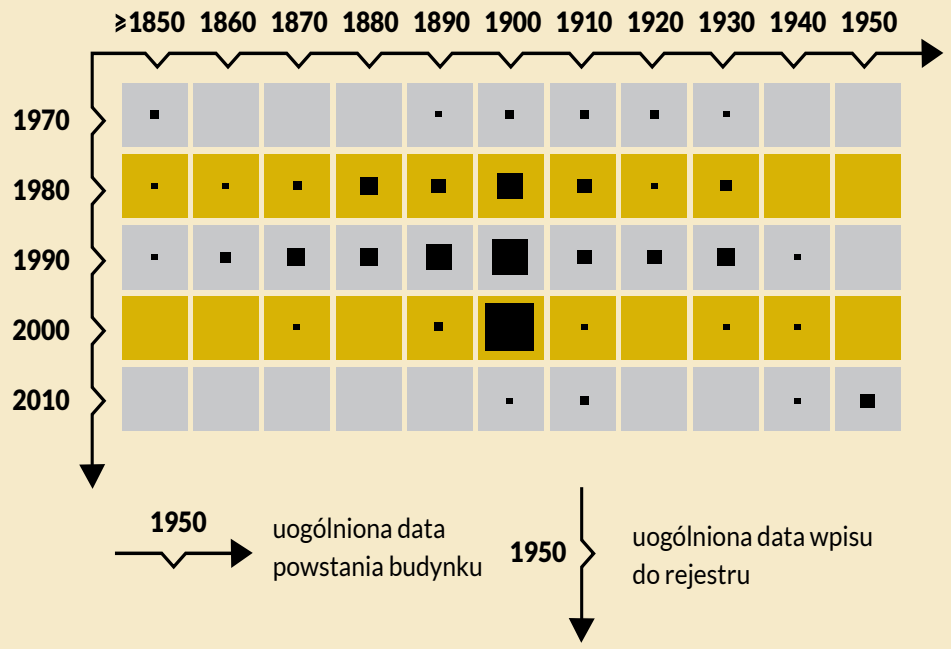

Uogólniona data powstania budynku oraz uogólniona data wpisu do rejestru zabytków na przykładzie Katowic. 
Relatywnie klarowny termin, jakim jest „zabytek”, ustępuje jednak stopniowo miejsca nieoczywistemu pojęciu dziedzictwa. Pojęciem tym posługują się już nie tylko konserwatorzy, historycy sztuki czy kulturoznawcy. Weszło ono bowiem także do żargonu ekonomistów, planistów przestrzennych, operatorów turystycznych i specjalistów od zarządzania. Termin „dziedzictwo kulturowe” jest dziś obecny w wielu dokumentach strategicznych opracowywanych przez władze miast. Często pojęcie dziedzictwa bywa przywoływane w dyskusjach na temat rozwoju lokalnego oraz rewitalizacji [Murzyn-Kupisz, 2012, s. 24]. Uzasadnione jest zatem pytanie o to, z jakiego powodu zaczęło ono zyskiwać na popularności oraz czy termin „zabytek" stał się niewystarczający? Z badań wynika, że choć wskazanie różnicy między zabytkiem a dziedzictwem sprawia problemy, wiele osób intuicyjnie zauważa, że dziedzictwo jest pojęciem szerszym [Kozioł et al., 2013, s. 15-16]. Zachodzące zmiany zwięźle podsumowuje M. Murzyn-Kupisz: „Obecnie [...] odchodzi się bowiem od węższego pojęcia zabytku, rozumianego jako obiekt czy zespół materialny, na rzecz znacznie szerszego, ale i bardziej niejednoznacznego pojęcia »dziedzictwo kulturowe«" [2010a].

Pojęcie dziedzictwa odnosi się już nie tyko do pojedynczych, materialnych, zabytkowych obiektów, ponieważ obejmuje również ich zespoły i krajobrazy, uwzględnia zwyczaje, tradycje oraz atmosferę miejsca (łac. genius loci). Dzisiejsze spojrzenie na dziedzictwo oznacza, że może się nim stać rezultat każdej działalności człowieka, nie tylko artystycznej [Murzyn-Kupisz, 2010b]. W ostatnich dekadach nastąpiło poszerzanie zakresu znaczeniowego dziedzictwa, co znajduje odzwierciedlenie $w$ treści tzw. dokumentów doktrynalnych, opracowywanych przez gremia konserwatorskie [Kozioł et al., 2013, s. 13-14]. Zatem, współcześnie pod pojęciem dziedzictwa kulturowego rozumie się „wielość materialnych i niematerialnych wartości, które pozostawiły współczesnym poprzednie pokolenia" [Murzyn-Kupisz, 2010a]. Nietrafiony byłby jednak pomysł, by za dziedzictwo uznawać wszystko to, co powstało w przeszłości, ponieważ w takim przypadku dziedzictwo obejmowałoby także „coś wytworzonego wczoraj lub przedwczoraj” [Throsby, 2010, s. 75]. Stąd, jak pisał A. Tomaszewski, „Dziedzictwo kultury jest sprawą wyboru. [...] Jest nim nie to wszystko, co w spadku artystycznym i kulturalnym pozostawiły nam minione pokolenia, lecz to, co z niego chcemy przejąć na własność" [2000, s. 9]. Wskazówka ta daje podstawy, by twierdzić, iż nie tylko od specjalistów, ale przede wszystkim od współczesnych społeczeństw oraz ich interpretacji zasobów kulturowych będzie zależeć, co ze spuścizny poprzedników uznane zostanie za dziedzictwo [Broński, 2006].

Podstawowe rozróżnienie, stosowane do kategoryzacji dziedzictwa kulturowego, dzieli je na dziedzictwo niematerialne oraz dziedzictwo materialne. Po pierwsze, za dziedzictwo niematerialne uznaje się m.in. przekazy ustne, tradycje, rytuały, języki i praktyki społeczne. Druga kategoria - dziedzictwo materialne - odnosi się do obiektów i miejsc, które posiadają fizyczną postać, aczkolwiek wyodrębnia się w niej dodatkowy podział. Materialne zasoby dziedzictwa są bowiem z jednej strony ruchomościami (m.in. obrazami lub dziełami sztuki użytkowej), jak też obiektami i miejscami trwale związanymi z przestrzenią (zespołami urbanistycznymi i ruralistycznymi, obiektami sakralnymi, budowlami obronnymi, obiektami użyteczności publicznej, zamkami, pałacami, dworami, budynkami mieszkalnymi, obiektami folwarcznymi, budynkami gospodarczymi, obiektami przemysłowymi, cmentarzami, obszarami zieleni urządzonej, czy zabytkami archeologicznymi).

Stosunkowo trudnym zadaniem jest oszacowanie wielkości zasobu dziedzictwa, ponieważ - jak wcześniej wspomniano - jest ono kategorią zależną od bieżącej interpretacji. W związku z tym, dla uzmysłowienia skali dziedzictwa najczęściej przywołuje się statystyki dotyczące obiektów uznanych za zabytki w świetle obowią- 
zującego prawa. Według danych Narodowego Instytutu Dziedzictwa na przełomie lat 2012 i 2013 najrozleglejszą kategorią zabytków w Polsce - ujętych w rejestrze zabytków - były zabytki ruchome, liczące blisko 235000 obiektów. W następnej kolejności znajdowały się zabytki nieruchome - z niemal 66500 wpisanymi obiektami. Ostatnią kategorię stanowiły zabytki archeologiczne w liczbie ponad 7600 [Kozioł et al., 2013, s. 24-25]. Statystyki te wskazują również, że najpowszechniejszą kategorią zabytków nieruchomych są w Polsce obiekty mieszkalne (wyk. 4.1). Obraz ten pozwala stwierdzić, że stan zachowania dominującej części dziedzictwa zależy zatem od znajdowania kompromisu pomiędzy praktyką konserwatorską a codziennymi potrzebami wielu ludzi zamieszkujących najliczniejszą kategorię obiektów budynki mieszkalne.

Wykres 4.1. Liczba obiektów nieruchomych wpisanych do rejestru zabytków w Polsce według kategorii (stan na dzień 31.12.2012)

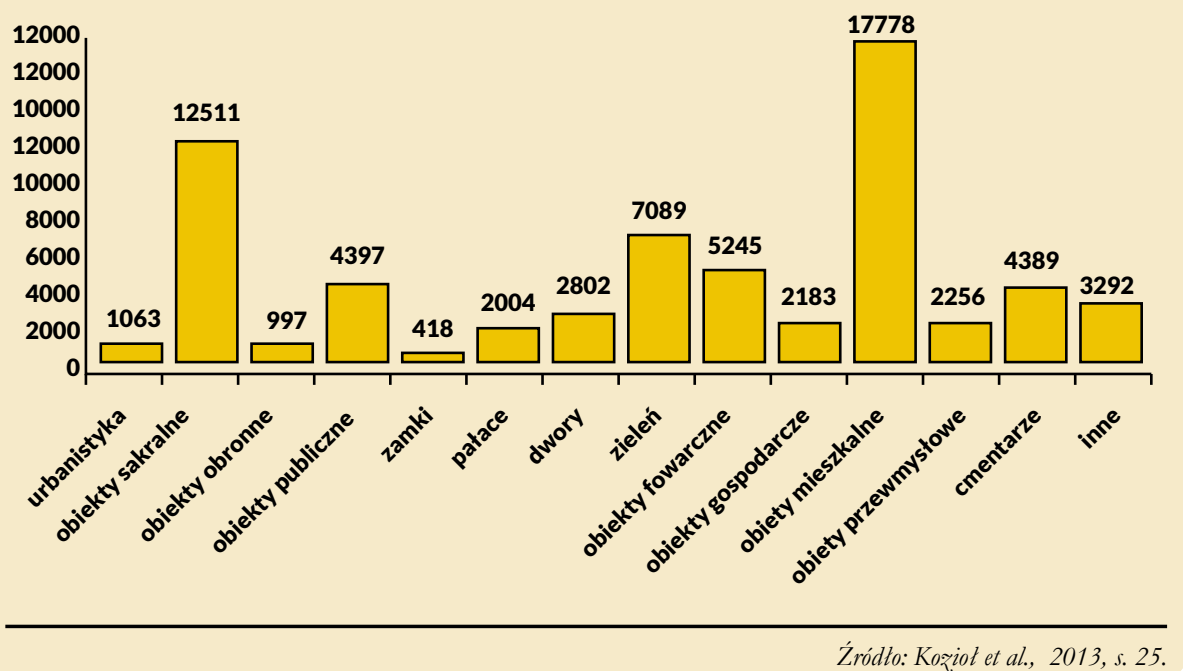

Zagadnienia poruszane w niniejszym rozdziale skupiają się przede wszystkim na dziedzictwie materialnym, a w szczególności na zabytkowych nieruchomościach, za pomocą których najczęściej ilustrowane są omawiane kwestie. Aczkolwiek, z perspektywy tożsamości miasta, której poświęcona jest dalsza część rozdziału, niematerialne zasoby dziedzictwa należy ocenić jako równie istotne.

\subsubsection{Dziedzictwo kulturowe jako zasób ekonomiczny}

U progu trzeciego tysiąclecia propagować zaczęto koncepcję zrównoważonego rozwoju, zwanego także podtrzymywalnym. Społeczność międzynarodowa doszła do wniosku, że człowiek dysponuje ograniczonymi zasobami, a gospodarowanie nimi musi odbywać się w sposób odpowiedzialny (zob. EkoMiasto\#Środowisko, rozdział: Zrównoważony rozwój miast). Stało się jasne, że dalszy rozwój cywilizacji nie może być prowadzony egoistycznie, ale musi uwzględnić potrzeby przyszłych pokoleń i pozwolić im na ich zaspokajanie. W Deklaracji z Maastricht zawarto przekonanie, że ochrona środowiska przyrodniczego człowieka jest jednoznaczna 
z ochroną jego środowiska kulturowego [Kobyliński, 2001, s. 34]. Od tego momentu zaczęło funkcjonować pojęcie zintegrowanego środowiska człowieka, łączącego w sobie oba wymienione typy. Pojęciem dziedzictwa zespolono ze sobą dwa aspekty: kulturowy i przyrodniczy. Podejmowane wysiłki na rzecz ochrony środowiska przyrodniczego znalazły wkrótce swoje odzwierciedlenie w podejściu do kwestii dziedzictwa kulturowego. Zaczęto je postrzegać jako rodzaj bogactwa, stanowiącego odbicie i wyraz swoich stale ewoluujących wartości, tradycji i wierzeń; bogactwa, którym należy umiejętnie gospodarować w interesie przyszłych pokoleń [Kozioł et al., 2013, s. 14].

Jak wcześniej zasygnalizowano, dziedzictwo kulturowe przez długi czas pozostawało w obszarze zainteresowań nauk humanistycznych. Dlaczego zatem ekonomiści zainteresowali się kategorią dziedzictwa kulturowego i jaki pożytek niesie ich zaangażowanie w tym zakresie? Wśród przyczyn wskazywane jest wytworzenie się rynku dziedzictwa kulturowego. Jak pisze J. Purchla, dziedzictwo przestało być „sacrum”, stając się „towarum” [2005, s. 19]. Jesteśmy dziś świadkami m.in. powiększającego się obrotu historycznymi dziełami sztuki, wzrostem sektora turystyki, faworyzującego miejsca obfitujące $w$ dziedzictwo, zaś zabytkowe nieruchomości często stają się przedmiotem transakcji, na potrzeby których uruchamiane są środki finansowe o znacznej wielkości. Istotny jest również wątek zarządzania rozwojem społeczno-gospodarczym miast. Odkąd ciekawość miejsca i jego wizualna atrakcyjność uczestniczą w budowaniu przewagi konkurencyjnej w wyścigu o przyciąganie nowych mieszkańców [Glaeser et al., 2001] i inwestorów, dziedzictwo zaczęto postrzegać jako jeden z czynników rozwoju miast. W związku z powyższym, na znaczeniu w ostatnich latach zaczęły zyskiwać gospodarcze właściwości dziedzictwa, wykorzystywane przez oba sektory: publiczny i prywatny. Z kolei analizy ekonomiczne okazują się przydatne m.in. przy szacowaniu korzyści społeczno-gospodarczych, stanowiących efekt działań podejmowanych przy dziedzictwie, mając na uwadze ograniczoność zasobów finansowych [Murzyn-Kupisz, 2010a; Throsby, 2010, s. 74-75]. Jednocześnie, nie stanowią one substytutu ekspertyz dokonywanych pod względem konserwatorskim, artystycznym, historycznym czy społecznym, ponieważ są ich uzupełnieniem [Murzyn-Kupisz, 2012, s. 24].

Warto wyróżnić wybrane cechy, które opisują dziedzictwo kulturowe jako zasób ekonomiczny. Składniki tego zasobu są heterogeniczne (różnorodne); ich liczba stale się poszerza; zasób ten jest nieodnawialny i trudno zastępowalny; a także specyficzny i endogeniczny dla danego miasta oraz trudno przenaszalny.

Składniki dziedzictwa kulturowego należy uznać za heterogeniczne. Jak wyjaśniono na początku rozdziału, dziedzictwem kulturowym mogą być zarówno dobra niematerialne, jak i materialne (w tym ruchomości i nieruchomości). Co więcej, dziedzictwo kulturowe nie było - jak w przypadku wielu innych dóbr - stworzone w zamyśle, by funkcję dziedzictwa spełniać od początku. Dobra stają się bowiem dziedzictwem wraz z upływem czasu, a zasób dziedzictwa stale się poszerza, gdyż „przejawy teraźniejszej działalności ludzi stać się mogą dziedzictwem dla przyszłych pokoleń" [Kozioł et al., 2013, s. 17]. Skala tego zjawiska jest zależna od odkrywania i interpretacji przeszłości oraz wartości cenionych przez społeczeństwo, determinujących, czy dane dobro nabierze znaczenia kulturowego i czy zostanie uznane za część wspólnej spuścizny [Murzyn-Kupisz, 2010b].

Trzeba w tym miejscu dodać, że choć zakres dziedzictwa systematycznie się powiększa, zdarza się także, że jego zasób jest uszczuplany, np. w wyniku zniszczeń. Komentarz ten powinien zwrócić uwagę na kolejną cechę dziedzictwa kulturowego - nieodnawialność. Raz utracony element dziedzictwa może nigdy nie powrócić. Zjawisko to można zilustrować m.in. ograniczonym zasobem dziedzictwa materialnego, 
gdyż w każdej epoce „stworzona została skończona liczba przykładów każdej wyróżnialnej klasy zabytków" [Kobyliński, 2001, s. 38]. Raz zniszczony obiekt nigdy nie powróci w swej oryginalnej formie, a wynik każdej próby jego odtworzenia będzie interpretacją wartości reprezentowanych przezeń pierwotnie.

Nieodnawialność dziedzictwa wiąże się z kwestią jego trudnej zastępowalności. Dziedzictwo, jako część kapitału kulturowego, posiada nie tylko wartości ekonomiczne, ale cechuje się także wartościami kulturowymi. Oznacza to, że stosunkowo łatwo znaleźć substytut dla dziedzictwa, odpowiadający jego cechom użytkowym, aczkolwiek zastępowalność dziedzictwa drastycznie maleje, gdy na znaczeniu zyskuje wartość kulturowa. Dla przykładu, schronienie można zapewnić dowolnym obiektem mieszkalnym, który może, choć nie musi, być zabytkiem. Mimo to, współczesny obiekt najprawdopodobniej nie będzie w stanie w prosty sposób zastąpić historycznych zabudowań, właśnie ze względu na ich wartość kulturową [Thorsby, 2012, s. 51].

Jak stwierdził G. Piccinato „wszystkie miasta są historyczne (ale niektóre bardziej)" [1997, s. 19]. Istotnie, dziedzictwo kulturowe można zidentyfikować we wszystkich miastach, aczkolwiek, będą się one różniły posiadanymi zasobami dziedzictwa, co związane jest z odmienną trajektorią procesów ich rozwoju. Miasta, które rozwijały się już w czasach starożytnych, mogą do dziś szczycić się pamiątkami z tamtego okresu. Nie jest to możliwe w przypadku miast, które powstały w okresie uprzemysłowienia. Te, z kolei, będą się cechować większym zasobem zabytków techniki na swoim terenie. Oznacza to, że zasób dziedzictwa jest za każdym razem specyficzny i endogeniczny dla danego miasta. Tym samym jest on zarazem zasobem trudno przenaszalnym, wynikającym z unikalnego splotu wydarzeń historycznych i ludzi zamieszkujących każde miasto.

\subsubsection{Wartość dziedzictwa kulturowego}

Wartość dziedzictwa kulturowego przez długi czas była rozpatrywana przede wszystkim przez kulturoznawców, pozostając w oderwaniu od kontekstu gospodarczego. $Z$ tego powodu uwaga badaczy skupiona była częściej na wartościach kulturowych dziedzictwa, takich jak wartość historyczna, symboliczna, duchowa, autentyczności, estetyczna czy społeczna. Ostatnie dekady rozszerzyły jednak analizowany zbiór wartości dziedzictwa o kategorię ekonomiczną, w obrębie której wartości można najogólniej podzielić na dwie podkategorie: użytkowe oraz pozaużytkowe. Oznacza to, że zarówno kulturoznawcy, jak i ekonomiści są zainteresowani określeniem wartości dziedzictwa kulturowego, choć ich punkty widzenia różnią się. Innymi słowy, współcześnie postrzegana wartość dziedzictwa kulturowego wyraża się sumą obu kategorii wartości - kulturowych oraz ekonomicznych (rys. 4.1) [Murzyn-Kupisz, 2010a; Rojas, 2012, s. 145; Throsby, 2010, s. 83].

Kategoria wartości kulturowych obejmuje pozaekonomiczne korzyści, jakie społeczeństwo czerpie dzięki obecności dziedzictwa. Wartości składające się na tę kategorię, choć od dawna wykorzystywane przez środowisko konserwatorskie, jest stosunkowo trudno zmierzyć [Murzyn-Kupisz, 2010a]. Wartość historyczna dziedzictwa kulturowego oznacza, że dany obiekt lub miejsce było w przeszłości świadkiem wydarzenia lub postaci istotnych dla losów świata, kraju, regionu lub miejsca. Dzięki wartości historycznej dziedzictwo staje się swoistym łącznikiem pomiędzy pokoleniami. Dziedzictwo kulturowe może również wyrażać wartości podzielane przez daną społeczność. W takim przypadku mówi się o wartości symbolicznej dziedzictwa kulturowego. Warto jednak zauważyć, że kategoria wartości symbolicznej jest bliska kategorii wartości duchowej, za sprawą której społeczność utożsamia się 
z danym obiektem lub miejscem. Wartość duchowa często wiąże się z praktykami religijnymi oraz oddawaniem szacunku osobom zmarłym. Wreszcie, dziedzictwo może cechować się wartością autentyczności, oznaczającej, iż dziedzictwo to jest autentyczne, unikalne, niezmiennie trwające w swej formie od bardzo długiego czasu. Ludzie mogą także czerpać przyjemność z przebywania w miejscach pięknych i harmonijnych, o ciekawej formie, a dziedzictwo często jest takimi przymiotnikami przez nich określane. Oznacza to, że zazwyczaj przypisuje się dziedzictwu kulturowemu wartość estetyczną. Ostatnią wartością identyfikowaną w kategorii wartości kulturowych dziedzictwa jest wartość społeczna: obiekty lub miejsca dziedzictwa mogą gromadzić ludzi w określonej przestrzeni, stwarzając okazję do interakcji między nimi.

\section{Rysunek 4.1. Wartość dziedzictwa i jego wartości składowe}

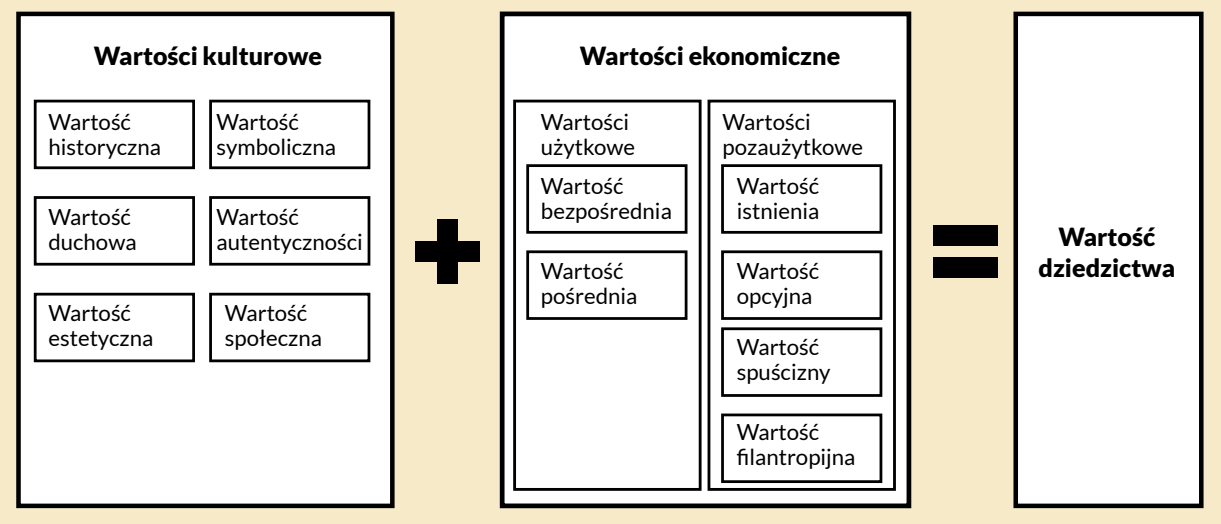

Źródto: opracowanie wtasne na podstawie Murzyn-Kupisz, 2010a; Rojas, 2012; Throsby, 2010.

Wartość jest jednocześnie jedną z podstawowych kategorii wykorzystywanych w teorii ekonomii, w myśl której przypisywanie określonej wartość rzeczom czyni z nich dobra ekonomiczne, zaspokajające ludzkie potrzeby. Jak pisał L.M. Pierson: „Nadanie czemuś wartości oznacza, że niechętnie jest się pozbawianym takiej rzeczy, natomiast z przyjemnością się je zdobywa" [Klaassen, 1988, s. 181]. Na wartość ekonomiczną dziedzictwa składają się wartości użytkowe oraz wartości pozaużytkowe. Wartości użytkowe dotyczą wszystkich dóbr i usług, które są przez dziedzictwo generowane [Murzyn-Kupisz, 2010a] i najczęściej wyrażają się one w cenie (np. nieruchomości na rynku lub biletu wstępu do danego obiektu). Warto jednak zauważyć, że wartość dziedzictwa może być określona w ujęciu bezpośrednim (np. przynosząc właścicielowi dochód z wynajmu powierzchni w obiekcie zabytkowym) lub w ujęciu pośrednim (np. ceny niezabytkowych nieruchomości zlokalizowanych w bliskim sąsiedztwie historycznych budynków często bywają wyższe dzięki swemu otoczeniu, zaś przestrzenne nagromadzenie dziedzictwa może pozytywnie wpływać na atrakcyjność odbioru przestrzeni miejskiej) [Rojas, 2012, s. 146].

Pozaużytkowe wartości ekonomiczne dziedzictwa wiążą się z sytuacją, kiedy dziedzictwo stanowi wartość dla określonych podmiotów, choć nie jest ono przez nie ani nabywane, ani konsumowane. Po pierwsze, część osób może uznać, że dziedzic- 
two ma wartość samo w sobie, albo, iż jest czymś istotnym dla szerszej grupy osób i z tego powodu warte jest zachowania, mimo iż sami nie zamierzają stać się użytkownikami dziedzictwa. Wartość, jaką przypisują oni dziedzictwu, nosi miano wartości istnienia. Jej przykładem są zbiórki funduszy na prace konserwatorskie przy zabytkach, których uczestnikami często są osoby zamieszkujące w dużym oddaleniu od lokalizacji danego obiektu, a mimo to chcące wspomóc wysiłek przywrócenia jego świetności. Po drugie, są także i tacy ludzie, którzy choć nie korzystają z dziedzictwa w danym momencie, będą zainteresowani jego użytkowaniem w przyszłości. Sytuacja ta ma miejsce np. wtedy, kiedy dana osoba zamieszkuje obszar peryferyjny miasta, ale w razie potrzeby chce mieć możliwość użytkowania jego historycznego centrum zasobnego w dziedzictwo. Przykład ten wskazuje, że istnieje wartość opcyjna, w przypadku której część ludzi będzie zainteresowana zachowaniem dziedzictwa, aby w bliższej lub dalszej przyszłości móc stać się jego użytkownikami. Trzecim przypadkiem będzie ten, kiedy ludzie cenią sobie dziedzictwo, choć nie mają ani nie będą mieli zamiaru go odwiedzać. Ich motywem działania może być jednak chęć przekazania dziedzictwa następnym pokoleniom. Ten rodzaj wartości dziedzictwa określa się mianem wartości spuścizny. Po czwarte, stosunkowo często w obecnych realiach gospodarczych zdarza się, że dziedzictwo wykorzystywane jest także do kreowania wizerunku określonych organizacji i przedsiębiorstw. Wielokrotnie można spotkać się z przeznaczaniem określonych nakładów pieniężnych na remont lub utrzymanie zabytku w zamian za posługiwanie się tytułem jego „mecenasa”. Takie działanie pozwala bowiem skuteczniej kreować markę wśród określonej grupy odbiorców. W tym przypadku będziemy mówić o wartości filantropijnej dziedzictwa [Rojas, 2012, s. 147]. Kończąc, warto zauważyć, że wartości pozaużytkowe dziedzictwa są zdecydowanie trudniejsze do wyrażenia w pieniądzu. Aczkolwiek udało się opracować metody ich pomiaru, czerpiąc z doświadczeń badaczy rozwijających metody wyceny wartości środowiska przyrodniczego.

Można zadać sobie pytanie o to, dlaczego wartość dziedzictwa kulturowego powinna być rozpatrywana z wykorzystaniem obu perspektyw, tj. kulturowej i ekonomicznej? W przypadku podejmowania jakichkolwiek działań przy dziedzictwie istotny jest bowiem ich bilans, określany relacją pomiędzy korzyściami ekonomicznymi i kulturowymi [Murzyn-Kupisz, 2010a]. Aby zilustrować to zagadnienie, posłużmy się dwoma przypadkami. W pierwszym, zwiększeniu wartości kulturowej zabytku (np. przez jego restaurację) może towarzyszyć także wzrost wartości ekonomicznej (np. za sprawą ulokowania w takim obiekcie nowej, dochodowej funkcji). Drugim wariantem byłaby sytuacja, w której przekształcenie zabytku na nową funkcję komercyjną (wzrost wartości użytkowej) wiązałoby się z utratą wartości kulturowych (np. w drodze wyburzenia istotnej części obiektów historycznych, przesądzających o charakterze większego zespołu zabytkowych zabudowań).

\subsubsection{Interesariusze na rynku dziedzictwa kulturowego}

Konsekwencją uznania dziedzictwa za dobro ekonomiczne jest stwierdzenie, że istnieje rynek dziedzictwa [Purchla, 2005, s. 19], na którym obecni są różnorodni aktorzy, pełniący odmienne role, podzielający różne wartości oraz kierujący się odmiennymi motywami w swym działaniu [Rojas, 2012, s. 147-149]. Wśród najważniejszych aktorów (podmiotów, interesariuszy) na rynku dziedzictwa kulturowego M. Murzyn-Kupisz wymienia następujące ich grupy: właściciele i posiadacze dziedzictwa; władze i administracja publiczna; organizacje pozarządowe; społeczność lokalna; naukowcy i specjaliści; publikatory oraz podmioty pozalokalne [Murzyn-Kupisz, 2010b]. 
Wielu aktorów - podmioty prywatne (osoby fizyczne i prawne), jednostki sektora publicznego, organizacje pozarządowe czy też kościoły i związki wyznaniowe - dysponuje prawami własności zarówno do zabytków nieruchomych, jak i do zabytkowych ruchomości. Stanowią oni kategorię właścicieli i posiadaczy dziedzictwa. Wraz z transformacją polityczną i gospodarczą zmniejsza się w Polsce udział własności państwowej i komunalnej w obszarze dziedzictwa kulturowego, a coraz większa jego część staje się własnością prywatną. Właścicielem dziedzictwa można stać się na wiele sposobów, m.in. otrzymując w spadku pamiątkę rodzinną lub celowo dążąc do zakupu obiektu zabytkowego. Zagrożeniem może być sytuacja, w której właściciel dziedzictwa nie zamierzał nim się stać. Może ona bowiem rodzić komplikacje, polegające bądź na braku możliwości, bądź na niechęci do finansowania niezbędnych prac konserwatorskich. Sytuacjom takim próbują zapobiegać z jednej strony dotacje ze środków publicznych na prace prowadzone przy obiektach zabytkowych, a z drugiej ograniczenia w dysponowaniu własnością nakładane prawem na właścicieli dziedzictwa.

Rola władz i administracji publicznej w obszarze dziedzictwa kulturowego jest rozległa. Wiele spośród europejskich systemów zarządzania dziedzictwem kulturowym - w tym polski - traktuje dbałość o dziedzictwo kulturowe jako obligatoryjne zadanie administracji publicznej. W Polsce jest ono obowiązkiem obu szczebli administracji: centralnej i terytorialnej. Dbałość o dziedzictwo kulturowe ze strony administracji publicznej może wyrażać się na wiele sposobów. Władze - z ramienia społeczności - są właścicielami wielu obiektów zabytkowych oraz pełnią rolę ich zarządców. Z kolei utrzymanie obiektów zabytkowych zarówno publicznych, jak i prywatnych często możliwe jest właśnie dzięki finansowaniu zapewnianemu przez budżet centralny i budżety samorządów lokalnych. Dzieje się to zazwyczaj poprzez przekazywanie różnego rodzaju dotacji na remonty zabytków, ale także w drodze stosowania instrumentów pośrednich, takich jak ulgi w podatkach od nieruchomości. Innym obszarem aktywności administracji publicznej wiążącym się z dbałością o dziedzictwo kulturowe jest jego promocja, nieraz wykorzystywana do budowania wizerunku miasta.

Organizacje pozarządowe podejmują różnego rodzaju aktywności na rzecz dziedzictwa kulturowego. Mogą organizować wsparcie finansowe, pozwalające na podejmowanie prac konserwatorskich i prowadzenie badań nad zabytkami, ale także angażować lokalne społeczności poprzez działania popularyzatorskie i edukacyjne. Wiele organizacji pozarządowych tworzy grupy poparcia na rzecz zmian regulacji prawnych w zakresie zarządzania dziedzictwem kulturowym. Organizacje pozarządowe skupione w obszarze dziedzictwa cechują się różną skalą aktywności: mogą prowadzić działania o zasięgu międzynarodowym (np. ICOMOS - Międzynarodowa Rada Ochrony Zabytków), krajowym (m.in. TOnZ - Towarzystwo Opieki nad Zabytkami) czy też lokalnym. Członkowie organizacji pozarządowych są jedną z tych grup interesariuszy, którzy najprędzej dostrzegają wartości dziedzictwa i dążą do upowszechnienia wiedzy na ich temat.

Mieszkańcy miasta (społeczność lokalna) to kolejna grupa interesariuszy na rynku dziedzictwa. Choć nie muszą oni dysponować tytułem prawnym do obiektu zabytkowego, często łączy ich związek emocjonalny z danym miejscem lub obiektem i mają wiedzę o jego historii. Podobnie, jak w przypadku właścicieli i posiadaczy dziedzictwa, społeczność lokalna może dziedzictwo sobie cenić, ale równie często może nie podzielać zainteresowania dziedzictwem, wykazywanego przez specjalistów i naukowców. Dzieje się tak zwłaszcza wtedy, gdy obiekt - w skutek braku prac konserwacyjnych i modernizacyjnych - jest zniszczony oraz kojarzony z zacofaniem technicznym (np. historyczny budynek wielkomiejskiej kamienicy 
pozostający bez wyposażenia w pełen zakres mediów). Niedogodności wiążące się z jego codziennym użytkowaniem mogą w takim przypadku przysłonić wartości kulturowe dziedzictwa.

Jedna fasada, odmienne priorytety i preferencje

Dyskusje prowadzone na temat działań remontowych prowadzonych przy obiektach zabytkowych często uwidaczniają różnice w priorytetach i preferencjach interesariuszy na rynku dziedzictwa kulturowego. Konserwatorzy zabytków dbają o to, aby forma obiektu zabytkowego nie ulegała zbytnim przekształceniom. Dzięki temu obiekt wciąż pozostaje bliski oryginałowi i mimo upływu czasu stanowi przykład epoki, w której powstał. Mieszkańcy zabytkowego budynku mogą jednak nie podzielać tej perspektywy, zwłaszcza kiedy zajmowany przez nich budynek nie budzi oczywistych skojarzeń z zabytkiem. Taka sytuacja jest domeną m.in. międzywojennej architektury modernistycznej, której wyraz architektoniczny wciąż ma wiele cech bliskich współczesnemu budownictwu. Poniższe rysunki wskazują, że konserwatorzy zabytków i mieszkańcy mogą odmiennie wyobrażać sobie pożądaną formę budynku. W tym przypadku mieszkańcy i konserwatorzy zabytków różnili się między sobą zdaniem na temat pożądanego koloru ścian, podziałów okiennych, formy balkonów czy też umiejscawiania na elewacji budynku dodatkowych instalacji i urządzeń. Przykład ten jest wskazówką, że sukces podejmowanych działań remontowych przy obiektach zabytkowych w znacznej mierze wynika z umiejętności znalezienia kompromisu pomiędzy praktyką konserwatorską a potrzebami i wyobrażeniami mieszkańców.

Pożądany obraz elewacji budynku mieszkalnego z lat 30. XX w. w oczach:

a) konserwatora zabytków,

b) mieszkańców.

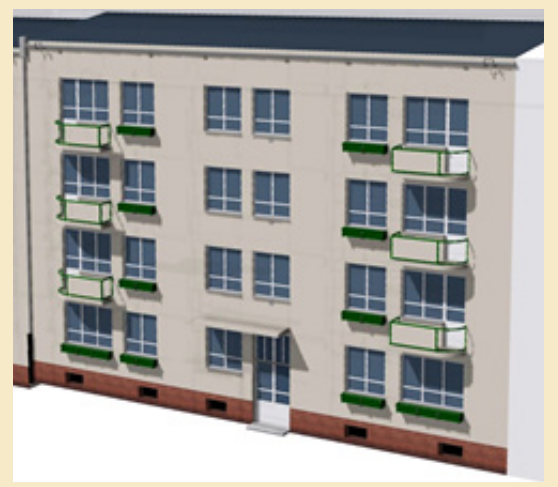

a)

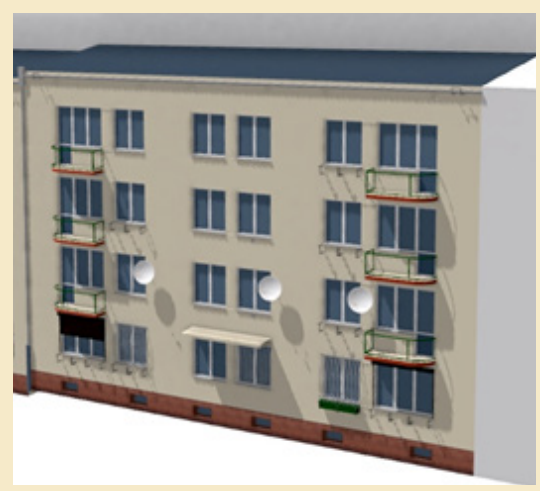

b)

Źródto: opracowanie wlasne na podstawie Zasina, 2015.

Naukowcy i specjaliści najczęściej jako pierwsi dostrzegają wartości dziedzictwa. Działo się tak m.in. w przypadku dziedzictwa miast poprzemysłowych czy też ostatnio odkrywanej spuścizny modernizmu. Grupa naukowców i specjalistów nie jest zazwyczaj właścicielami dziedzictwa, aczkolwiek wspomagają oni jego posiadaczy wiedzą i doświadczeniem. To właśnie ta grupa często odpowiada za proces „uszlachetnienia” dziedzictwa, w ramach którego prowadzi się działalność popularyzatorską i edukacyjną, uświadamiającą pozostałe grupy podmiotów o wartościach dziedzictwa. 
Wszelkiego rodzaju media - telewizja, radio, prasa, Internet - uczestniczą w upowszechnianiu wiedzy na temat dziedzictwa i kształtują na nie popyt (np. prezentując atrakcyjne destynacje turystyczne bogate w zasoby dziedzictwa). Coraz częściej media wykorzystują także swoją pozycję do prowadzenia publicznej dyskusji na temat stanu dziedzictwa kulturowego. Warto zauważyć, że w wybranych miastach Polski lokalne media wspierają akcje obrony obiektów zabytkowych, którym grozi wyburzenie, a także publikują bezpłatne tematyczne dodatki, prezentujące lokalne zasoby dziedzictwa kulturowego.

Przedstawicieli ostatniej kategorii interesariuszy - podmiotów pozalokalnych - łączy fakt pochodzenia spoza obszaru, w którym dziedzictwo jest umiejscowione. Są to m.in. turyści, pielgrzymi, ale także obsługujące ich przedsiębiorstwa i instytucje. Podmioty te stają się konsumentami dziedzictwa tylko na chwilę, przybywając w daną lokalizację. Aktywność turystów i pielgrzymów może przynosić miastu korzyści, takie jak dochody budżetowe stanowiące efekt wpływów z podatków lokalnych. Aczkolwiek, ich obecność może objawiać się także negatywnymi aspektami, np. zatłoczeniem.

Podsumowując, przy podejmowaniu przedsięwzięć dotyczących dziedzictwa kulturowego niezbędne staje się poznanie motywów kierujących działaniem poszczególnych interesariuszy, ponieważ pozwala to zrozumieć zależności pomiędzy nimi, a także uniknąć potencjalnych konfliktów. Przy czym, wybrani aktorzy mogą być uczestnikami jednocześnie kilku zidentyfikowanych powyżej grup. Przykładem niech będzie sytuacja, w której mieszkaniec zabytkowej kamienicy, będąc przedstawicielem lokalnej społeczności, jest także działaczem organizacji pozarządowej, a podczas wakacji staje się turystą użytkującym miejsca i obiekty dziedzictwa w innej lokalizacji.

\subsubsection{Uwarunkowania popytu na dziedzictwo kulturowe}

Przy działaniach podejmowanych na rzecz rozwoju współczesnych miast konieczne jest znajdowanie odpowiedzi na pytanie o to, co warunkuje i intensyfikuje popyt ze strony lokalnych społeczności i podmiotów pozalokalnych na dziedzictwo.

Po pierwsze, przyjmuje się, że wzrost dynamiki zmian zachodzących w szeroko rozumianym otoczeniu człowieka powoduje wzrost zainteresowania przeszłością. Zainteresowanie to przekłada się na wzrost popytu na dziedzictwo, będące łącznikiem pomiędzy przeszłością i teraźniejszością. Obserwacja ostatnich dekad wydaje się potwierdzać tę zależność: postępujący wzrost zaciekawienia dziedzictwem kulturowym zachodzi równolegle z dynamicznymi zmianami o charakterze gospodarczym, społecznym, kulturowym i technologicznym [Murzyn-Kupisz, 2010b].

Po drugie, poszukując zmiennych determinujących wysokość popytu na dziedzictwo, warto rozważyć zależność, którą dostrzegł X. Greffe: wzrost zainteresowania dziedzictwem jest funkcją m.in. stanu jego utrzymania czy też „jakości” dziedzictwa (wyk. 4.2). W przypadku, gdy wyjściowy stan utrzymania dziedzictwa jest zły, zainteresowanie nim jest niskie, co wzmacnia tylko proces jego degradacji. Z kolei, jeśli wyjściowy poziom utrzymania dziedzictwa jest wysoki, dziedzictwo będzie miało większą szansę na zaistnienie w świadomości lokalnej społeczności i podmiotów pozalokalnych oraz na wzbudzenie ich zainteresowania. Istnieje zatem pewien określony poziom wydatków, stanowiący nakłady sektorów publicznego i prywatnego, który pozwoli utrzymać dziedzictwo w pożądanym stanie, podtrzymującym zainteresowanie nim. Opracowanie X. Greffego wskazuje też, że będą istniały sytuacje, w których niezbędna stanie się interwencja zmierzająca do pobudzenia zainteresowania dziedzictwem. Celowi temu służyć mogłyby takie bodźce, jak zwolnienia 
z podatków od nieruchomości - zachęcające właścicieli do podejmowania prac renowacyjnych, a także działania informacyjne i edukacyjne - upowszechniające wiedzę na temat dziedzictwa [Greffe, 2004].

Wykres 4.2. Zależność między poziomem zainteresowania dziedzictwem a jego stanem utrzymania / ,jakością".

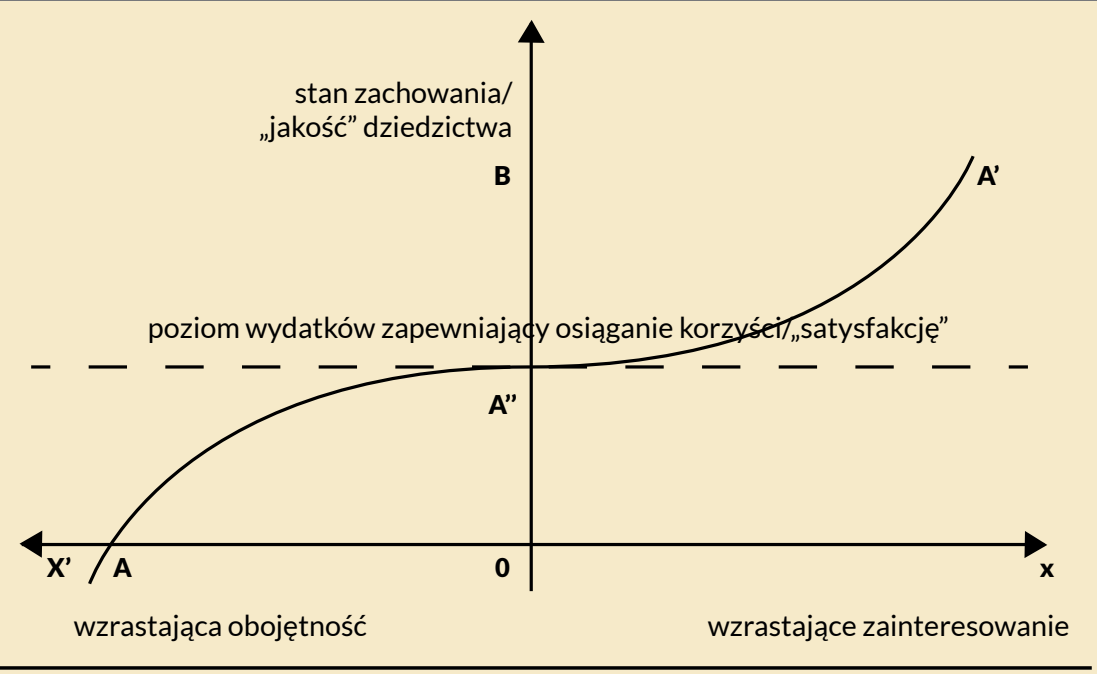

Źródto: Greffe, 2004, s. 304, za: Murayn-Kupisz 2012, s. 44.

Skala popytu na dziedzictwo jest kluczowa dla wielkości jego podaży. Z tego powodu umiejętność wciągnięcia dziedzictwa w procesy rozwojowe staje się dziś zasadniczym wyzwaniem dla miast. Niewystarczający popyt na dziedzictwo może bowiem doprowadzić do zjawiska określanego przez J. Purchlę mianem „nadpotencjału dziedzictwa", który występuje w sytuacji, kiedy organizm miejski nie jest w stanie zagospodarować posiadanego dziedzictwa, w skutek czego jest ono tracone [Purchla, 2005, s. 59].

\subsubsection{Wybrane płaszczyzny oddziaływania dziedzictwa na rozwój miasta}

Można wyodrębnić kilka płaszczyzn, w ramach których dziedzictwo oddziałuje na rozwój miasta. W pierwszej kolejności warto rozważyć kwestie związane z decyzjami lokalizacyjnymi ludzi. Sukces miasta często utożsamia się z napływem nowych mieszkańców, ludzie bowiem, dążąc do maksymalizacji swojej satysfakcji i porównując ze sobą różne miejsca, w których chcieliby zamieszkać, wybierają ostatecznie te, które uznają za najkorzystniejsze. Z uwagi na rosnący dobrobyt oraz wykształcenie i mobilność ludzi, wśród czynników, które przyciągają ich do miast, zaczęto wymieniać m.in. atmosferę miasta, jego architektoniczne piękno, ład zagospodarowania przestrzennego, a także ofertę kulturalną. Dziedzictwo kulturowe ma do odegrania w tych procesach istotną rolę, ponieważ jak mało który składnik, buduje ono nastrój miasta i przesądza o jego architektonicznym wyrazie, a tym samym zasadniczo współuczestniczy w budowaniu atrakcyjnego wizerunku miasta, przyciągającego mieszkańców i inwestorów.

Drugą z rozważanych płaszczyzn oddziaływania dziedzictwa na rozwój miasta będzie jego uczestnictwo we wzmacnianiu poziomu jakości życia mieszkańców. 
Druga połowa $X X$ w. cechowała się zwiększeniem roli szeroko rozumianej konsumpcji w wyjaśnianiu procesów wzrostu i rozwoju gospodarczego, także w skali miast [Glaeser et al., 2001]. Tym samym, zaczęto oczekiwać, że wyposażenie miast oraz zagospodarowanie ich przestrzeni wyjdzie naprzeciw rosnącym pragnieniom mieszkańców. Zasób dziedzictwa w mieście, za sprawą posiadanej wartości kulturowej, może być zatem jednym z głównych elementów odpowiadających na potrzeby mieszkańców w zakresie kultury. W tym przypadku warto odwołać się także do dziedzictwa niematerialnego, ponieważ to właśnie ono w znacznej mierze umożliwia budowanie lokalnej tożsamości, za sprawą wykształconej historycznie miejscowej kultury i tradycji. Ponieważ dziedzictwo cechuje się także innymi wartościami użytkowymi, może ono zaspokajać także inne potrzeby ludności, wpływające na poziom i jakość ich życia: obiekty dziedzictwa stanowią wielokrotnie miejsca rekreacji, a za sprawą swych wartości estetycznych, uczestniczą w pozytywnym waloryzowaniu zamieszkiwanej przestrzeni miasta.

Najczęściej rozpatrywanym aspektem rozwoju, który pojawia się w kontekście dyskusji o dziedzictwie kulturowym, jest najprawdopodobniej turystyka. Nie ulega wątpliwości, że atrakcyjny zasób dziedzictwa ma siłę przyciągania do miasta turystów, którzy - najczęściej uprzednio poinformowani o składnikach tego zasobu będą dążyć do osobistego ich doświadczenia. Wraz z bogaceniem się społeczeństw, zwiększają się możliwości jego przedstawicieli w zakresie aktywności turystycznej. Umasowienie turystyki niesie korzyści, jakie miasto będzie z tego tytułu uzyskiwać. Wyróżnić można w tym przypadku chociażby wzrost zatrudnienia w sektorze turystyki czy też rosnące wpływy z podatków odprowadzanych przez przedsiębiorstwa z tej branży. Aczkolwiek, często zapomina się o tym, że masowa turystyka może prowadzić do zbyt intensywnej eksploatacji dziedzictwa, stopniowo degradującej jego wartość kulturową, a ponadto może wywoływać efekt kongestii. Stopniowo zauważa się także, że najbardziej popularne destynacje turystyczne stają się zamkniętymi i zestandaryzowanymi światami, ukierunkowanymi na obsługę ruchu turystycznego, w których z każdym rokiem coraz trudniej dostrzec ich lokalną specyfikę oraz codzienne życie ich mieszkańców.

Oddziaływanie dziedzictwa nie kończy się na wskazanych powyżej obszarach. Literatura przedmiotu dostarcza wiadomości o tym, że zasób dziedzictwa kulturowego może oddziaływać na strukturę rynku nieruchomości, wspomaga tworzenie i utrzymywanie miejsc pracy, pozwala budować kapitał społeczny, może stanowić katalizator procesów rewitalizacji, a także być źródłem kreatywności [szersze ujęcie tematu: Murzyn-Kupisz, 2012, s. 80-85]. Podsumowując, dylemat „dziedzictwo czy rozwój”, choć jeszcze kilka lat temu mógł wydawać się zasadny, obecnie jest już tylko pozorny [Purchla, 2005, s. 73]. Aczkolwiek, przedstawiciele ekonomiki miejskiej i regionalnej podkreślają, iż „samo występowanie na danym obszarze określonego zasobu nie zapewnia jednak automatycznie rozwoju. Może on nastąpić wtedy, gdy dany zasób staje się realnym, aktywnym czynnikiem tego rozwoju i można go wykorzystać dla podejmowania różnych działań społecznych i gospodarczych" [Jewtuchowicz, 2013, s. 113]. Zasób, jakim jest dziedzictwo, będący wciąż „tylko” potencjałem, musi zacząć być zrównoważenie i odpowiedzialnie wykorzystywany, aby stać się aktywem istotnym dla procesów rozwojowych.

\subsubsection{Zarządzanie dziedzictwem kulturowym. Nowe wyzwania}

Ostatnie dziesięciolecia przyniosły istotne zmiany w postrzeganiu dziedzictwa kulturowego oraz w charakterze działań podejmowanych na jego rzecz. Model, w którym stosunkowo wąskie grono specjalistów zapewniało ochronę ograniczonej 
Skuteczne zarządzenie dziedzictwem powinno w szerokim zakresie wykorzystywać tzw. instrumenty „miękkie”, tworzące bodźce dla interesariuszy, skłaniające ich do pożądanych zachowań [Thorsby, 2012, s. 60], a także angażować różne podmioty we „wspólną sprawę”, jaką jest dziedzictwo. Przykładem mogą być wysiłki podjęte w latach 2012-2015 przez biuro Miejskiego Konserwatora Zabytków w Łodzi. Jego pracownikom udało się zwalczyć chaos panujący w parterach użytkowych kamienic przy reprezentacyjnej ulicy miasta - Piotrkowskiej - podejmując „nieszablonowe” działania. Urzędnicy do przedsięwzięcia zaprosili z jednej strony właścicieli sklepów, a z drugiej młodych architektów. Architekci opracowali projekty witryn sklepowych, z których bezpłatnie mogli skorzystać przedsiębiorcy. Kupcy - zachęceni efektem prac projektowych - zastosowali się do wskazówek i od nowa zaaranżowali witryny sklepów. Działania edukacyjne prowadzone przez urzędników Miejskiego Konserwatora Zabytków następnie poszerzono, opracowując m.in. Księgę standardów ulicy Piotrkowskiej. Wskazano w niej, jak powinny wyglądać witryny sklepowe oraz partery użytkowe, aby z jednej strony nie szpeciły zabytkowych kamienic i krajobrazu ulicy, a z drugiej, aby były oceniane jako atrakcyjne przez potencjalnych klientów.

Witryny w parterach kamienic z ulicy Piotrkowskiej 5 i 142 w Łodzi przed i po działaniach podjętych przez Miejskiego Konserwatora Zabytków.
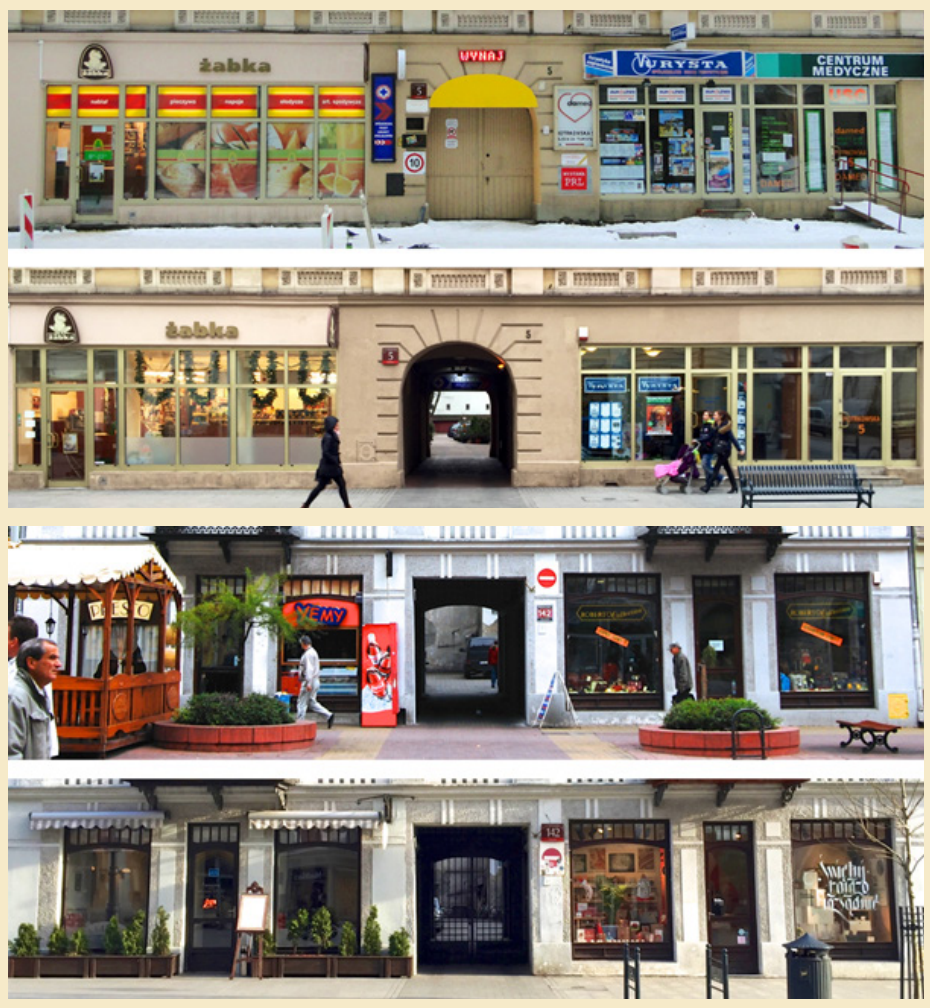

Źródto: opracowanie własne z wylkorzystaniem fotografii J. Zasiny (po) i Biura Miejskiego Konserwatora Zabytków $w$ Lodzi (przed). 
liczbie zabytkowych obiektów, przestaje odpowiadać wyzwaniom współczesności. W jego miejsce pojawia się wieloaspektowe zarządzanie dziedzictwem, biorące pod uwagę perspektywy różnorodnych aktorów i spoglądające na problemy dziedzictwa przez pryzmat wielu dyscyplin, a zatem uwzgledniające pełne spektrum wartości dziedzictwa. Ochrona pojedynczych obiektów ustępuje pola zarządzaniu rozległymi krajobrazami kulturowymi, w których coraz ważniejszą rolę przypisuje się dziedzictwu niematerialnemu [Murzyn-Kupisz, 2012, s. 64-65]. Zadaniem współczesnego zarządzania dziedzictwem kulturowym jest już nie tylko zachowywanie i ochrona dziedzictwa, ale także jego zrównoważone i odpowiedzialne wykorzystywanie. Dziś powszechny staje się pogląd o tym, że skuteczna ochrona dziedzictwa jest równoznaczna z umiejętnością włączenia go w procesy rozwoju, ponieważ tylko użytkowane dziedzictwo ma szansę na przetrwanie. Wyzwanie to jest jednak niezwykle trudne, ponieważ rodzi pytania o możliwy zakres ingerencji w dziedzictwo i zmusza do poszukiwania harmonijnego kompromisu pomiędzy kanonami ochrony a wymogami życia i prawami ekonomii [Purchla, 2005, s. 54]. Warto przy tym pamiętać, że odpowiedzialność za utrzymanie dziedzictwa przestała być wyłącznie domeną sektora publicznego i specjalistów, stając się w znacznej mierze zobowiązaniem właścicieli prywatnych i mieszkańców. Przede wszystkim zaś koncepcja dziedzictwa wymaga dziś od lokalnych społeczności ciągłego zadawania pytań o interpretację przeszłości oraz o jej znaczenie dla teraźniejszości i przyszłości.

\subsection{Tożsamość miasta}

\subsubsection{Wymiary i znaczenie tożsamości miasta}

Współczesny świat kształtowany jest przez procesy integracyjne gospodarki i społeczności, a obok dokonujących się zmian w globalnej koncentracji kapitału widoczna staje się potrzeba określenia lokalnej tożsamości różnych grup społecznych. Skutkiem tego zjawiska staje się aktywne współuczestnictwo mieszkańców w rozwoju urbanistycznym miejsc zamieszkania lokalnych społeczności [Wrana, 2011, s. 17]. Ponadto, rozpowszechnienie zasady zrównoważonego rozwoju sprawiło, że szczególna uwaga skoncentrowana została na konieczności ochrony środowiska przyrodniczego oraz walorów kulturowych miast. Równocześnie rozwijana jest idea społecznego uczestnictwa w zachowaniu i odtwarzaniu historycznej tożsamości miejsc [Wrana, 2011, s. 23-24]. Jest ona wyrazem troski o warunki życia przyszłych pokoleń. W myśl zasady zrównoważonego rozwoju podkreśla się, że ochrona środowiska jest jedną z dróg zachowania tożsamości miejsca, gdyż każde miejsce posiada swój zapis historyczny, a proces kulturowego kształtowania miejsca został zapisany w jego strukturze jako swoisty kod DNA [Wrana, 2011, s. 23-24].

W literaturze brak jednoznacznego pojęcia tożsamości miasta. Jest to rezultatem istnienia wielu podejść do tego zagadnienia. Tożsamość miasta określana jest jako stosunek zachodzący między każdym przedmiotem a nim samym, jako „identyczność”, „równość”. Na gruncie psychologii architektury tożsamość definiowana jest jako głęboka zależność między elementami, istniejąca mimo zewnętrznego braku podobieństwa [Lenartowicz, 1997, s. 138]. Tożsamość jest więc głęboką zależnością zachodzącą między człowiekiem a postrzeganym przez niego krajobrazem (otoczeniem, miejscem) wraz z jego historycznie nawarstwionymi elementami, takimi jak treść (kultura, tradycja miejsca) i forma, czyli kanon miejsca [Wrana, 2011, s. 25].

W literaturze przedmiotu zwraca się uwagę na tożsamość terytorialną w podziale na indywidualną oraz zbiorową. Tożsamość terytorialna (indywidualna) określana jest jako umysłowa reprezentacja i emocjonalna ocena danego obszaru, który 
człowiek włącza do koncepcji samego siebie i postrzega jako swoją częćć [Łukowski, 2002, s. 82-83]. Tożsamość terytorialna zbiorowa (grupowa) jest z kolei poczuciem więzi łączących człowieka z innymi ludźmi zamieszkującymi wspólnie dany obszar, poczuciem przynależności do grupy. Tożsamość terytorialna, wzmacniana działaniami prowadzonymi w ramach marketingu miejsc, stanowi istotny element procesu rozwoju współczesnych jednostek terytorialnych z uwagi na powiązanie emocjonalne danej społeczności z miejscem swojej egzystencji [Raszkowski, 2013, s. 225-235]. Ponadto, wyznacznikiem tożsamości terytorialnej jest istnienie więzi emocjonalnej mieszkańców z danym terytorium, krajobrazem, innymi ludźmi zamieszkującymi to terytorium, a także z materialnym i duchowym dziedzictwem kulturowym danego obszaru. Tożsamość terytorialna rozpatrywana może być również w kontekście postaw, które mieszkańcy i użytkownicy przyjmują wobec danej przestrzeni lokalnej (np. miasta) [Mazurek, 2008].

Tożsamość miasta wydaje się być specyficzną formą tożsamości, która wywodzi się z pojęć, takich jak „tożsamość społeczna” (zbiorowa), „tożsamość kulturowa”, a także „tożsamość terytorialna”. Nowa Karta Ateńska definiuje tożsamość miejsca (miasta) jako istotną wartość, która wymaga umocnienia i ciągłości. Podkreśla ona, że każde miasto powinno rozwinąć swój własny, unikatowy charakter społeczny i kulturowy, który wynika z jego historii, jak i zachodzących współczesnych zmian i wydarzeń. Rezultatem tego ma być utrzymanie i wzmocnienie różnorodności charakteru oraz tożsamości miast i regionów różnych części Europy. Jednym z ważnych elementów budujących tożsamość miejsca jest genius loci, który człowiek odczuwa jako coś, co kształtuje i definiuje jego otoczenie [Wiśniewska, 2012, s. 89-91]. Duch miejsca (łac. genius loci) to zespół lub ogół elementów materialnych (miejsc, krajobrazów, budynków, przedmiotów), niematerialnych (wspomnień, przekazów ustnych, dokumentów pisanych, rytuałów, festiwali, profesji, rzemiosła, umiejętności), wszelkich walorów fizycznych (z zapachami włącznie) i duchowych, które nadają sens emocjonalny miejscu. „Duch buduje miejsce, a miejsce tworzy ducha”, stąd też zapisy Nowej Karty Ateńskiej postulują podjęcie działań zmierzających do tworzenia unikalnego krajobrazu miast, wyrażającego genius loci i uwydatniającego jego charakter. Wskazuje się również na konieczność ochrony walorów kulturowych i środowiskowych miast, gdyż są one w coraz większym stopniu czynnikami konkurencyjności miasta, a ich tożsamość i jakość życia odgrywać będzie szczególną rolę w ich rozwoju [Wiśniewska, 2012, s. 77-83].

Tożsamość wydaje się należeć do pozytywnych odczuć i wzniosłych doznań, stąd zapisy Nowej Karty Ateńskiej wzywają do zachowania i budowania tożsamości miast, co zakłada, że tożsamość przedstawia wartość zasługującą na utrwalenie [Wiśniewska, 2012, s. 77-83].

Tożsamość miasta w rozważaniach marketingu terytorialnego definiowana jest jako „zbiór cech charakterystycznych, które wyróżniają miasto spośród innych i wyrażają się wszelkimi działaniami, jakie są podejmowane, tworząc jego swoistą osobowość i charakter" [Łuczak, 2005, s. 47-53]. Ta osobowość podobna jest do osobowości człowieka i wydaje się bardzo złożona, stąd należy ją rozpatrywać w wielu aspektach. Tożsamość miasta dotyczy identyfikacji mieszkańców z określonym miejscem (miastem, dzielnicą, ulicą itp.), jej przestrzenią, ludźmi, kulturą, tradycją czy dziedzictwem materialnym [Boryczka i Sokołowicz, 2011].

Tożsamość miasta kształtowana jest przez pewne elementy niezmienne (rys. 4.2), będące kręgosłupem-szkieletem dla innych jej składowych, oraz teraźniejszej lub zakładanej pozycji miasta. Szkielet tożsamości powinny stanowić elementy stałe, charakterystyczne dla miasta, których zmiana w czasie jest niemożliwa lub długotrwała np. rodowód historyczny, dziedzictwo kulturowe, położenie miasta, warunki 
przyrodnicze, tradycje itp. Elementami zmiennymi kształtującymi tożsamość są jej kulturowo-socjologiczne składniki, cele miasta, potencjał intelektualny, zlokalizowany kapitał, sytuacja rynkowa, kultura organizacyjna, a także promocja wewnętrzna i zewnętrzna miasta itp. [Boryczka, 2008, s. 217-230]. Ta elastyczność w podejściu do tożsamości miasta wynika z konieczności dostosowywania się do zmieniających się uwarunkowań wewnętrznych i zewnętrznych. Tożsamość bowiem ewoluuje wraz ze zmianami potrzeb i warunków realiów społeczno-gospodarczych. Oznacza to również, że tożsamość ma dynamiczny charakter i jest procesem, który - jak wskazuje literatura przedmiotu oraz praktyka jednostek samorządu terytorialnego - można planować i kreować [Florek, Glińska i Kowalewska, 2009, s. 38].

Rysunek 4.2. Elementy tożsamości miasta.

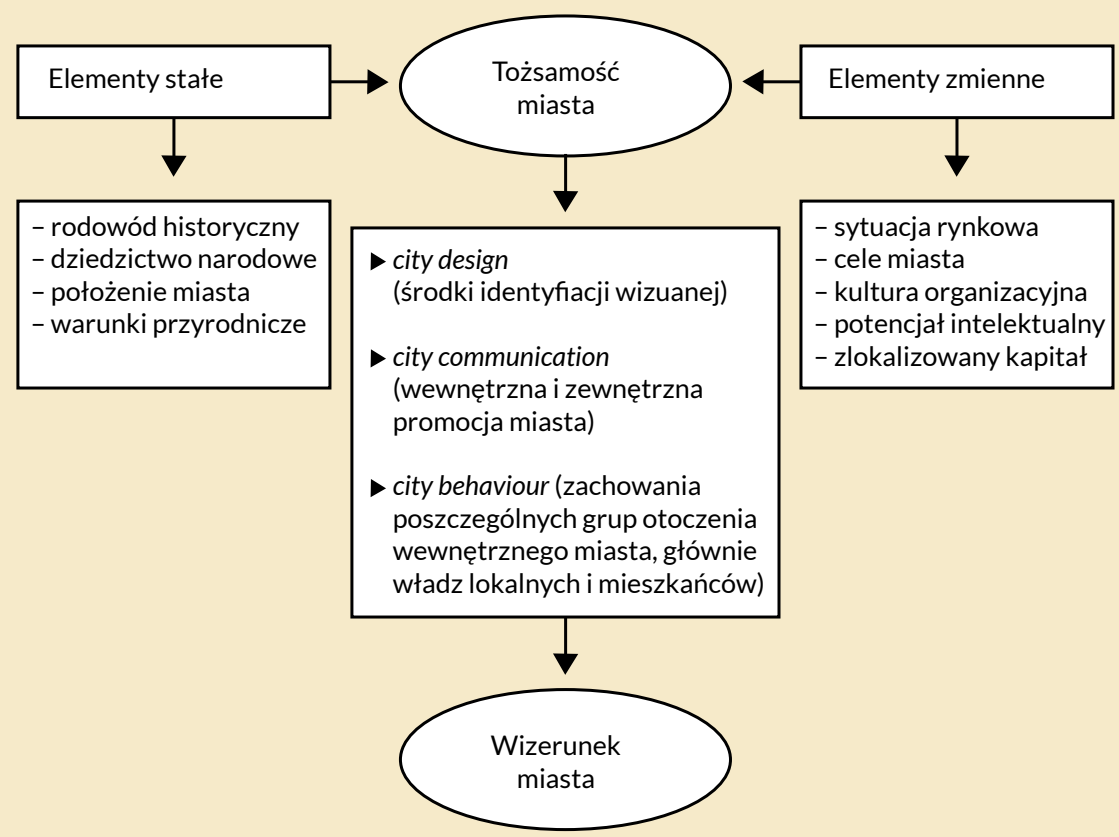

Źródto: opracowanie na podstawie Luczak, 2005, s. 50 oraz Szromnik, 2012, s. 148-153.

Obiekty będące nośnikami materialnych cech identyfikacyjnych, które są symbolami obszaru w świadomości społecznej, jego znakami identyfikacyjnymi, to najczęściej historyczne obiekty pełniące funkcję żywego przekazu historycznego. Takie cechy, jak dawność, wartość estetyczna, unikatowość, oryginalność, autentyczność, które budzą skojarzenia historyczne i emocjonalne, nadają obszarowy charakter unikatowości i kształtują tożsamość miejsca. Warto jednak zwrócić uwagę, że nie tylko obiekty historyczne czy zabytkowe, odwołujące się do starych, wielowiekowych tradycji tworzą podstawy kształtowania tożsamości zbiorowej. Dla budowania tożsamości społeczności lokalnych, a czasami tylko pewnych grup, znaczenie mają z pozoru wydawałoby się przeciętne miejsca, które jednak tworzą historię i przestrzeń symboliczną dla tej wybranej grupy ludności. Czasami skromne i zwykłe elementy przestrzeni stają się znaczące i ważne, uzupełniając dominujące w przestrzeni wartości innej kultury odgrywają także istotną rolę w kształtowaniu miejskiego krajobrazu kulturowego i tożsamości lokalnej [Karwińska, 2008, s. 90-96]. 
Na gruncie marketingu terytorialnego (zob. EkoMiasto\#Zarządzanie, rozdział: Marketing miasta) funkcjonuje koncepcja tożsamości miasta oparta na trzech elementach:

- obrazie miasta,

- systemie komunikowania się z otoczeniem,

- systemie zachowania się miasta [Szromnik, 2012, s. 148-153].

Obraz miasta obejmuje wszystkie składniki decydujące o obliczu miasta. Obok elementów architektury i urbanistyki miasta są to także symbole, nazwy, slogany, barwy, pomniki, elementy infrastruktury. Najbardziej rozpowszechnioną metodologią badania obrazu miasta jest propozycja K. Lyncha, który elementy składowe obrazu miasta opisuje pięcioma kategoriami: drogami, krawędziami, rejonami, węzłami oraz punktami orientacyjnymi [Lynch, 2011]. Jest to więc suma elementów, dzięki którym miasto prezentuje się odbiorcom wewnętrznym i zewnętrznym.

System komunikowania się z otoczeniem, czyli konkretnymi grupami odbiorców, to system komunikacji marketingowej. Jest to całokształt środków i technik wymiany informacji z grupami interesantów. Istotą tego systemu jest świadome działanie mające na celu nawiązanie i podtrzymywanie prawidłowych relacji między miastem a jego otoczeniem. Władze samorządowe mają tu więc kluczową rolę, a sprawnie i efektywnie funkcjonujący system powinien charakteryzować się dużą dostępnością, przepustowością informacyjną, wiarygodnością, reaktywnością i dużą indywidualizacją [Szromnik, 2012, s. 148-153].

System zachowania się miasta (jego mieszkańców, użytkowników, przedstawicieli władz, innych grup społecznych) określany jest jako kultura miasta. Kultura miasta odzwierciedla wzorce, reguły i normy zachowań mieszkańców. Obejmuje ona normy społeczne i prawne, zasady etyczne, kulturę osobistą mieszkańców, zasady porządku publicznego, zwyczaje i lokalne tradycje. W literaturze przedmiotu tę kulturę miasta, czy też inaczej - system zachowania się miasta, określa się mianem osobowości miasta. Jest ona rdzeniem jego tożsamości. Innymi słowy, jest to specyficzny charakter miasta.

Każde miasto ma swoją tożsamość. Jest ona mniej lub bardziej określona, ale zawsze występuje. Na tę tożsamość składa się: miejsce - środowisko i jego natura, społeczność, historia, kultura. W procesie kreowania i definiowania tożsamości miasta należy:

- wskazywać i podkreślać cechy charakterystyczne dla miasta, które stanowią o jego istocie,

- wskazywać i podkreślać cechy, które odróżniają miasto od innych,

- stale eksponować w czasie wybrane i wskazane we wcześniejszym etapie cechy miasta co zapewni odpowiednią dbałość o kreowanie wyraźniej jego tożsamości [Łuczak, 2005, s. 47-53].

Sens tożsamości odnajduje się przez niekończącą się artykulację, czyli przez stałe eksponowanie w czasie wybranych cech miasta. Stworzenie i wprowadzenie do społecznej świadomości definicji tożsamości miasta, która zawiera obiektywne informacje o danym miejscu i obala nieprawdziwe i złe mity, tworzy pozytywną hierarchię ważności w podejmowaniu decyzji. Artykulacja ta „może odwrócić negatywne procesy dezintegracyjne zachodzące w mieście". Jasne i precyzyjne określenie tożsamości miasta powinno służyć również do zmiany świadomości mieszkańców i użytkowników miasta i w konsekwencji - zmiany wizerunku miasta. We współczesnych europejskich dyskusjach o rewitalizacji istnieje opinia, że uznanie tożsamości danego miejsca jest warunkiem koniecznym i niezbędnym w procesie odnowy miast [Boryczka, 2008, s. 217-230] (zob. EkoMiasto\#Zarządzanie, rozdział: Marketing miasta). 


\subsubsection{Przemiany przestrzenne, gospodarcze, społeczne i ustrojowe w kształtowaniu tożsamości polskich miast}

Miasta są złożonymi systemami, które powstają i zmieniają się w wyniku długotrwałego procesu rozwoju. Podsystemy miasta - ekonomiczny, społeczny, przestrzenno-organizacyjny - kształtują się pod wpływem oddziaływania różnych czynników. Przemiany te odzwierciedlają zjawiska zachodzące w obrębie miasta, a także w szerszym kontekście społeczno-kulturowym, politycznym, ekonomicznym [Karwińska, 2008, s. 146-150]. Zmiany polityczne, społeczne i ekonomiczne, które dokonują się w Polsce od 1989 r., znacząco wpływają na tożsamość polskich miast. Wśród najważniejszych wymienia się transformację ustrojową, procesy globalizacji, metropolizacji oraz integrację europejską.

Globalizacja niesie ze sobą zjawiska, które silnie wpływają na identyfikację mieszkańców z miejscem zamieszkania i przebywania. Wśród tych zjawisk wskazuje się relatywizację (oznaczającą stałe porównywanie się do innych), fragmentację i detradycjonalizację. „W miarę nasilania się procesów o charakterze globalnym zamiast tożsamości formowanych przez kontekst lokalny pojawiają się także tożsamości ponadnarodowe. Obserwowany wzrost międzynarodowej migracji powoduje, że zostaje zerwana ciągłość tożsamości" [Dziekanowska, 2008, s. 33-46]. Idea odradzania się i budowania tożsamości miast jest formułowaniem na nowo tożsamości lokalnych w ramach wielkich tożsamości kształtowanych w dobie globalizacji.

Jak podkreśla się w literaturze przedmiotu, każda radykalna zmiana ma wpływ na tożsamość miasta, a może prowadzić nawet do jej kryzysu. Przykładem kryzysu tożsamości miasta jest sytuacja Łodzi: w skutek m.in. pierwszej i drugiej wojny światowej nastąpiła wymiana ludności miasta, co współcześnie - dziesiątki lat później - objawia się trudnościami w identyfikacji mieszkańców z miastem.

Wraz z procesem globalizacji i metropolizacji następują przekształcenia centralnych dzielnic wielkich miast m.in. w przestrzeń zdominowaną przez funkcje biurowe, handlowe i hotelowe. W krajobrazie polskich miast coraz częściej pojawiają się grodzone osiedla mieszkaniowe. Nowa zabudowa często sąsiaduje z socjalistycznymi osiedlami z wielkiej płyty, zdegradowanymi przestrzeniami strefy otaczającej centrum miasta i obszarami poprzemysłowymi. Co więcej, współcześnie jesteśmy świadkami uniformizacji nie tylko dóbr i usług, ale także architektury. Nowoczesne budynki, o uniwersalnej, podobnej na całym świecie formie niejednokrotnie zupełnie nie pasują do miejsc, w których są stawiane, zakłócając wygląd i percepcję jego wyjątkowego charakteru. Na skutek tych procesów zmienia się charakter i wygląd polskich miast, stają się one przestrzeniami silnych kontrastów społecznych, kulturowych oraz przestrzennych. Czynniki te przyczyniają się do rozmywania się i braku czytelności tożsamości polskich miast, utraty tego, co unikalne i wyjątkowe.

W wyniku procesu transformacji systemowej i otwarcia Polski na zagraniczne rynki produktów i usług oraz na zagraniczne wpływy gospodarcze i społeczne w polskich miastach dostrzegane są przejawy wpływu procesu globalizacji. W latach 90. XX w. w przestrzeni miast pojawiły się sklepy wielkopowierzchniowe, których obecność doprowadziła do upadku wielu drobnych przedsiębiorstw handlowych. Hiper-i supermarkety - zwyczajowo lokalizowane na obrzeżach miast - coraz częściej zaczęły powstawać w ich centrach. $Z$ biegiem czasu pojawiły się pierwsze galerie handlowe koncentrujące pod jednym dachem wielu najemców - głównie duże sieci handlowe. Otwarcie polskich rynków skutkowało pojawieniem się przedstawicieli międzynarodowych i globalnych sieci handlowych, marek odzieżowych (H\&M, Zara) i gastronomicznych (McDonald's, Starbucks) [Radziszewska, 2013, s. 125-147]. Ich pierwsze sklepy lokalizowane były przy głównych ulicach polskich miast, jednak wraz 
z powstawaniem galerii handlowych zaczęto je przenosić do nowych obiektów. Ich miejsce przy głównych ulicach zaczęły zajmować oddziały sieci bankowych, operatorów telefonicznych czy sklepy z używaną odzieżą. Przemiany te przyczyniły się do stworzenia w polskim społeczeństwie nowych wzorców konsumpcji.

Wiele zakładów przemysłowych nie wytrzymało konkurencji, inne zostały zamknięte lub sprywatyzowane. Upadek tych zakładów przyczynił się do wzrostu bezrobocia i pogorszenia sytuacji finansowej mieszkańców miast. W przestrzeni polskich miast pojawiły się opuszczone budynki fabryk i zakładów produkcyjnych oraz tereny poeksploatacyjne. Część z nich szybko zaadaptowano na działalność usługową, inne do dziś pozostają niezagospodarowane. Szczęśliwie, stopniowo zmienia się postrzeganie architektury poprzemysłowej, a coraz więcej jej przykładów znajduje nowe funkcje.

Z kolei wielkie zespoły mieszkaniowe, które powstawały w latach 70. i 80. XX w., będące niegdyś synonimem dobrobytu, współcześnie w wielu miastach stały się niechcianymi miejscami zamieszkania. Mieszkańcy o wyższych dochodach, wyższej pozycji zawodowej, lepiej wykształceni wyprowadzają się często poza granice miasta albo na tereny podmiejskie. Zatem, zjawiskiem, które istotnie wpływa na strukturę przestrzenną i funkcjonalną polskich miast, jest suburbanizacja, która zwiększa wciąż społeczną i przestrzenną polaryzację miasta. Zwalniające się mieszkania w obszarach centralnych miast coraz częściej przeznaczane są na wynajem, co skutkuje zjawiskiem tymczasowości zamieszkania. Niestety, duża rotacja mieszkańców nie sprzyja budowaniu więzi między mieszkańcami oraz więzi z miejscem zamieszkania. Sytuację komplikują problemy związane z grodzeniem i zamykaniem przestrzeni małych osiedli i wspólnot mieszkaniowych. Rytm pracy, brak czasu, specyficzny styl życia, dostępność elektronicznych sposobów komunikowania się wpłynął na relacje międzyludzkie, sąsiedzkie, które przybierają w wielu kręgach charakter instrumentalny.

Istotne zmiany, oddziałujące na tożsamość polskich miast, nastąpiły także w sferze ustrojowej. W procesie decentralizacji władzy w Polsce zwiększono kompetencje władz samorządowych. Możliwe stało się suwerenne planowanie i realizowanie działań w samorządach miejskich. Znaczenie tych przemian objawia się tym, że to właśnie władze samorządowe w znacznej mierze podejmują działania wzmacniające tożsamość i wizerunek miasta. Ponadto, w procesie decentralizacji władzy wprowadzono trójstopniowy podział terytorialny, w wyniku którego wiele miast wojewódzkich straciło status miasta wojewódzkiego. Dla części z nich oznaczało to pogorszenie sytuacji gospodarczej i społecznej, a także wizerunkowej.

\subsection{Tożsamość a wizerunek miasta}

Tożsamość miasta jest sumą elementów, które je identyfikują; zbiorem cech charakterystycznych dla miasta, wyróżniających je spośród innych i wyrażających się wszelkimi działaniami, które podejmowane są w mieście, tworząc jego swoistą „osobowość" i charakter. Są to tzw. wyróżniki tożsamości - atrybuty miasta, które warto eksponować i komunikować otoczeniu. Elementy tożsamości miasta powinny być wyznacznikami zachowań i podejmowanych działań, które mają na celu zaspokajanie potrzeb mieszkańców i użytkowników miasta. To swoiste ramy dla podejmowanych i planowanych działań. Określenie oraz wnikliwe rozważenie tożsamości całego miasta lub jego fragmentu należy podjąć przed przystąpieniem do jakichkolwiek działań miejskich. Wszystkie działania powinny być „podejmowane właśnie w ramach indywidualnej tożsamości każdego miasta, jednocześnie ją podkreślając i wzmacniając" [Łuczak, 2005, s. 47-53]. Efekty tych spójnych działań składają się na jasno określony i pozytywny wizerunek miasta. 
Wizerunek miasta jest coraz częściej postrzegany jako jeden z największych zasobów, który może posiadać jednostka terytorialna. Według P. Kotlera, wizerunek (image) można postrzegać jako sumę poglądów, postaw i wrażeń, które osoba lub grupa ma w stosunku do danego obiektu, którym może być nie tylko przedsiębiorstwo, lecz także produkt, marka, osoba i miejsce. Wizerunek miasta natomiast jest zestawem wrażeń i interpretacji powiązanych spontanicznie z określonym bodźcem fizycznym bądź społecznym, który kojarzy się z danym miejscem. Te skojarzenia wpływają na stan wiedzy o danym mieście. Stąd, coraz większą wagę przykłada się do percepcji miast przez ich użytkowników [Boryczka, Sokołowicz, 2011]. Wizerunek miasta to jego obraz i konsekwencja w świadomości społecznej, natomiast tożsamość to samoświadomość miasta. W literaturze przedmiotu istnieje pogląd, że „nie tyle istnieją elementy wizerunku miasta, co poszczególne elementy tożsamości mają swój wizerunek” [Stanowicka-Traczyk, 2008, s. 13-21]. Inaczej rzecz ujmując, tożsamość kształtuje wizerunek (rys. 4.3). Nigdy jednak nie jest on pełnym jej obrazem, a jedynie jego modyfikacją, weryfikowaną przez wiele czynników związanych m.in. z adresatami wizerunku miasta. Zależność pomiędzy tożsamością a wizerunkiem miasta ilustruje rys. 4.3.

\section{Rysunek 4.3. Tożsamość a wizerunek miasta}

\section{TOŻSAMOŚĆ MIASTA}

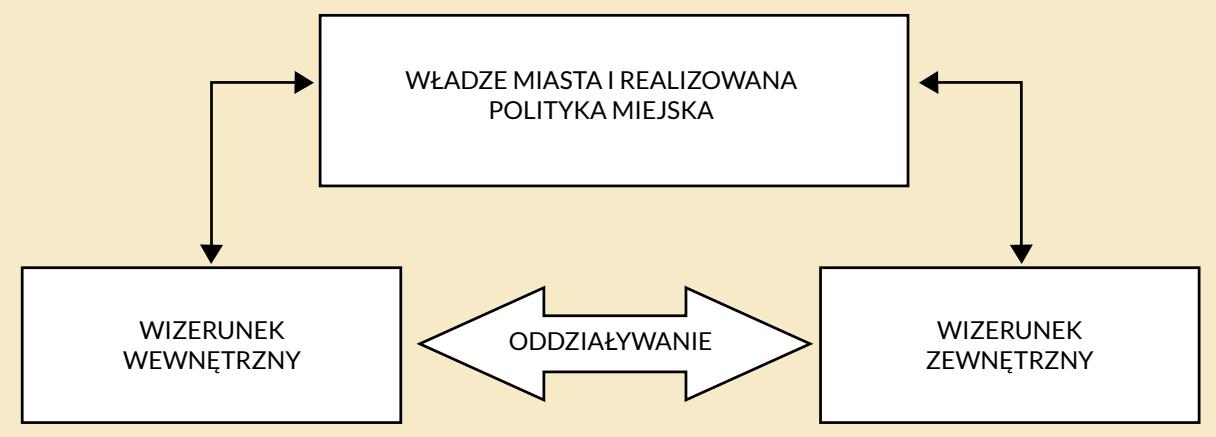

Źródto: Luczak, 2001, s. 84.

Punktem wyjścia doboru instrumentów kształtowania wizerunku powinna być identyfikacja wyróżników tożsamości miasta [Altkorn, 2002, s. 24]. Strategię kształtowania wizerunku wewnętrznego i zewnętrznego można budować na jednym mocnym, wyróżniającym się atucie albo na wielu jednocześnie. Mówi się wtedy, że wyróżniki tożsamości miasta mogą być skoncentrowane lub rozproszone. Podkreślić należy, że proces kształtowania wizerunku jest tym bardziej wyrazisty, im mniej jest wyróżników tożsamości, lepiej prezentujących tożsamość miasta [Stanowicka-Traczyk, 2007, s. 53-70].

Tożsamość miasta nie jest tylko zbiorem cech wyróżniających miasto, a pewnego rodzaju zadaniem dla jednostek samorządu terytorialnego, gdyż może podlegać kształtowaniu i wzmacnianiu, co w dużej mierze zależy od celów marketingowych i strategicznych rozwoju miasta [Florek, Glińska i Kowalewska, 2009, s. 37]. Tak, jak w kreowaniu wizerunku przedsiębiorstwa w rozważaniach dotyczących tożsamości firmy dużą rolę w tych działaniach przypisuje się kadrze kierowniczej, taką rolę 
również w procesie kreowania i definiowania tożsamości miasta powinna odgrywać władza samorządowa. Władze samorządowe ponoszą odpowiedzialność za politykę komunikacyjną, formułowanie przekazów skierowanych w stronę otoczenia, jak i wewnątrz miasta. Jako organ planujący i zarządzający odpowiedzialna jest za wdrożenia i przebieg działań podejmowanych na danym obszarze. Rola władzy samorządowej „wyraża się także w komunikowaniu się z otoczeniem przez zachowanie i podejmowane działania, a także środki wizualnej identyfikacji miasta" [Łuczak, 2005, s. 47-53; Boryczka, 2008, s. 217-230].

Podkreślić jednak należy, że władze samorządowe są głównym, ale nie jedynym kreatorem działań budujących tożsamość i wizerunek miasta. Wśród innych podmiotów, środowisk zaangażowanych w ten proces wskazać należy podmioty ze świata biznesu, nauki i edukacji oraz organizacji pozarządowych, instytucji samorządowych i rządowych. Ponadto społeczność lokalna świadoma wartości oferty miasta w sposób naturalny ma większą skłonność do podnoszenia poziomu swojej tożsamości i podejmowania działań na rzecz rozwoju miasta.

Na gruncie marketingu terytorialnego można wskazać wiele korzyści wynikających z kreowania i wzmacniania tożsamości miasta. Wśród nich są m.in. lepsze postrzeganie miasta $w$ kraju i za granicą, jako rozpoznawalnego i niejednokrotnie elitarnego miejsca czy też możliwość wyróżnienia go na tle innych miast. W wyniku oddziaływania marketingu terytorialnego wzrasta poczucie dumy mieszkańców miasta i prestiż związany z zamieszkaniem, wzrasta także poczucie przynależności mieszkańców do wspólnoty. Ponadto zmniejsza się skłonność mieszkańców do emigracji, a zamieszkanie $w$ danym mieście może stać się przejawem manifestacji statusu społecznego [Raszkowski, 2013, s. 225-235].

Kreowanie i wzmacnianie tożsamości miasta jest procesem długofalowym i powinno być realizowane konsekwentnie oraz z wykorzystaniem całego zestawu instrumentów. Proces ten powinien zostać uwzględniony w ogólnej koncepcji rozwojowej jednostek terytorialnych. Określenie i wzmacnianie tożsamości przyczynia się do integracji miasta, a także tworzy pozytywną hierarchię wartości w podejmowaniu decyzji i działań miejskich. Natomiast efekty tych spójnych skoordynowanych działań składają się na jasno określony i pozytywny wizerunek miasta. Stąd, kreowanie wizerunku i wzmacnianie tożsamości miasta są dziś kluczowymi kwestiami zarządców współczesnych miast i urbanistów. Wydaje się bowiem, iż globalizacja i rosnąca mobilność ludności powodują, że niezbędne staje się budowanie emocjonalnych więzi mieszkańców i przedsiębiorców z miejscem zamieszkania i pracą [Boryczka, Sokołowicz, 2010, s. 71-96].

\section{Bibliografia}

Altkorn J. (2002), Kształtowanie rynkowego wizerunku firmy, Wydawnictwo AE, Kraków. Ashworth G.J. (1997), Planowanie dziedzictwa, [w:] K. Broński, J. Purchla, Z.K. Zuziak (red.), Miasto historyczne. Potencjał dziedzictwa, Międzynarodowe Centrum Kultury, Kraków.

Boryczka E. (2008), Tożsamość Łodzi, czyli o prawdzie tego miasta, [w:] Z. Przygodzki, M.E. Sokołowicz (red.), Nowoczesne miasto. Badania, instrumenty, analizy, Wydawnictwo Biblioteka, Łódź.

Boryczka E.M., Sokołowicz M.E. (2010), Marka Łodzi jako czynnik budujący tożsamość Łódzkiego Obszaru Metropolitalnego, [w:] Z. Przygodzki, A. Suliborski (red.), Łódzka metropolia. Problemy integracji społecznej i przestrzennej, Wydawnictwo Biblioteka, Łódź. 
Boryczka E.M., Sokołowicz M.E. (2011), Tożsamość i wizerunek dużego miasta wobec międzynarodowej mobilności osób dobrze wykształconych. Przykład łodzi w oczach studentów łódzkich uczelni, „Zeszyty Naukowe Politechniki Poznańskiej”, nr 24 Architektura i Urbanistyka.

Broński K. (2006), Rola dziedzictwa kulturowego w rozwoju lokalnym. Doświadczenie polskie doby transformacji (po 1989 r.), „Zeszyty Naukowe Akademii Ekonomicznej w Krakowie", nr 706.

Dziekanowska M. (2008), Tożsamość społeczna a globalizacja, „Zeszyty Naukowe Uniwersytetu Szczecińskiego", nr 517.

Florek M., Glińska E., Kowalewska A. (2009), Wizerunek miasta: od koncepcji do wdrożenia, Wolters Kluwer, Warszawa.

Glaeser E.L., Kolko J. \& Saiz A. (2001), Consumer city, „Journal of Economic Geography", vol. 1(1).

Greffe X. (2004), Is heritage an asset or a liability?, „Journal of Cultural Heritage”, vol. 5(3).

Jewtuchowicz A. (2013), Terytorium i współczesne dylematy jego rozwoju, wyd. 2, Wydawnictwo UŁ, Łódź.

Karwińska A. (2008), Gospodarka przestrzenna. Uwarunkowania społeczno-kulturowe, Wydawnictwo Naukowe PWN, Warszawa.

Kącka A., Krupa A., Zasina J. (2013), Zabytki, o co to larmo?/Heritage architecture why the fuss?, [w:] Przyjemność eksperymentowania, Instytucja Kultury Katowice - Miasto Ogrodów, Katowice.

Klaassen L.H. (1988), Myśl i praktyka ekonomiczna a przestrzeń, Wydawnictwo UŁ, Łódź.

Kobyliński Z. (2001), Teoretyczne podstawy konserwacji dziedzictwa archeologicznego, Fundacja „Res Publica Multiethnica” \& Instytut Archeologii i Etnologii Polskiej Akademii Nauk, Warszawa.

Kozioł A., Trelka M. \& Florjanowicz P. (2013), Społeczno-gospodarcze oddziaływanie dziedzictwa kulturowego. Raport z badań społecznych, Narodowy Instytut Dziedzictwa, Warszawa.

Lenartowicz K. (1997), Słownik psychologii architektury dla studiujących architekturę, Skrypt Politechniki Krakowskiej, Kraków.

Lynch K. (2011), Obraz Miasta, Wydawnictwo Archivolta, Kraków.

Łuczak A. (2001), Wizerunek miasta, „Samorząd Terytorialny”, nr 1-2.

Łuczak A. (2005), Istota tożsamości miasta, „Samorząd Terytorialny”, nr 1.

Łukowski W. (2002), Społeczne tworzenie ojczyzn, Wydawnictwo Naukowe Scholar, Warszawa.

Mazurek M., 2008, Tożsamość przestrzenna jako wyznacznik zakorzenienia wśród mieszkańców współczesnych Kaszub, [w:] M. Kempny, G. Woroniecka, P. Załęcki (red.), Tożsamość i przynależność. O współczesnych przemianach identyfikacji kulturowych w Polsce i w Europie, Wydawnictwo Naukowe UMK, Toruń.

Murzyn-Kupisz M. (2010a), Barbarzyńca w ogrodzie? Dziedzictwo kulturowe widziane z perspektywy ekonomii, „Zarządzanie Publiczne”, nr 13.

Murzyn-Kupisz M. (2010b), Podmioty na rynku dziedzictwa kulturowego, „Studia Regionalne i Lokalne", nr 41.

Murzyn-Kupisz M. (2012), Dziedzictwo kulturowe a rozwój lokalny, Wydawnictwo UE w Krakowie, Kraków. 
Purchla J. (2005), Dziedzictwo a transformacja, Międzynarodowe Centrum Kultury w Krakowie \& Małopolska Szkoła Administracji Publicznej Akademii Ekonomicznej w Krakowie, Kraków.

Piccinato G. (1997), Wszystkie miasta sa historyczne (ale niektóre bardziej), [w:] K. Broński, J. Purchla, Z.K. Zuziak (red.), Miasto historyczne. Potencjat dziedzictwa, Międzynarodowe Centrum Kultury, Kraków.

Radziszewska J. (2013), Tożsamość miasta w kontekście przemian politycznych, ekonomicznych i społecznych we współczesnej Polsce. Przypadek Kielc, „Kwartalnik Kolegium Ekonomiczno-Społecznego. Studia i Prace", nr 3(15).

Raszkowski A. (2013), Marketing miejsc w kontekście wzmacniania i kształtowania tożsamości terytorialnej, [w:] Marketing przyszłości. Trendy. Strategie. Instrumenty, „Zeszyty Naukowe”, nr 775, Problemy zarządzania, finansów i marketingu, nr 30, Szczecin.

Rojas E. (2012), Governance in historic city core regeneration projects, [w:] G. Licciardi, R. Amirtahmasebi (eds), The Economics of Uniqueness, World Bank, Washington.

Stanowicka-Traczyk A. (2007), Instrumenty strategii kształtowania wizerunku na przykładzie miast polskich, „Studia Regionalne i Lokalne”, nr 3(29).

Stanowicka-Traczyk, A. (2008), Kształtowanie wizerunku miasta na przykładzie miast polskich, Oficyna Wydawnicza Branta, Bydgoszcz-Olsztyn.

Szromnik A. (2012), Marketing terytorialny. Miasto i region na rynku, Wolters Kluwer business, Warszawa.

Throsby D. (2010), Ekonomia i kultura, Narodowe Centrum Kultury, Warszawa.

Thorsby D. (2012), Heritage economics: A Conceptual framework, [w:] G. Licciardi, R. Amirtahmasebi (eds), The Economics of Uniqueness, World Bank, Washington.

Tomaszewski A. (2000), Dziedzictwo i zarządzanie, [w:] K. Gutowska (red.), Problemy zarządzania dziedzictwem kulturowym, Fundacja „Res Publica Multiethnica”, Warszawa.

Wiśniewska W. (2012), Krajobraz miejski. Odnowa i kreacja w procesie odnowy, Wydawnictwo PŁ, Łódź.

Wrana J. (2011), Tożsamość miejsca jako kryterium w projektowaniu architektonicznym, Politechnika Lubelska, Lublin.

Zasina J. (2015), Procedural facade scenarios as a supportive tool for modernism heritage protection, „Architecture, Civil Engineering, Environment”, vol. 8(2). 


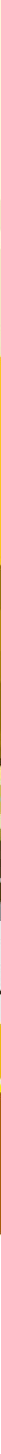

